\title{
ADALÉKOK A KEZDETEKHEZ, A KözgÁz ÉS A VILÁggAZdASÁgI INTÉZET ŐSTÖRTÉNETÉHEZ (Ahogy én láttam, és talán formáltam.)
}

\section{TALÁlKozÁs AZ ÚJ EGYETEMMEL}

1948-ban Szeghalmon, a Kissárrét „fővárosában” a Református Péter András gimnáziumban érettségiztem. Sokáig arra készültem, hogy vegyészmérnök leszek. Anyám testvére Csepelen gyógyszerész volt, gyerekük nem született, és arra számított, hogy majd én valamikor átveszem tőle a gyógyszertárat. Ez a bombázások miatt lehetetlenné vált.

A gimnáziumban a kémia mellett egyre jobban érdekeltek a XX. század háborúinak izgalmas társadalmi, gazdasági öszefüggései. Önképzőköri dolgozataimban is ezekkel foglalkoztam. Ettől még mehettem volna akár a müszaki egyetemre is. Adódott azonban egy érdekes lehetőség, amelyről egy barátom értesített, aki egy évvel előttem érettségizett. Ő már Pesten járt egyetemre és népi kollégista is volt. 1948-ban, húsvéti látogatásakor elmondta, hogy készül egy új, közgazdasági, társadalmi kérdésekkel foglalkozó egyetem. Arra kértem, írja majd meg, mikor indul és hogyan kell jelentkezni. Néhány hét múlva megírta, hogy a Szerb utcában lesz Pesten, a "József Nádor” helyén. Azt is javasolta, hogy elöször jelentkezzem valamelyik népi kollégiumba. Később konkrétan a Dózsa kollégiumot ajánlotta s megírta, kinek kell elküldeni a jelentkezést. Jelentkeztem az egyetemre és a kollégiumba is. Előbb vettek föl a Dózsába mint az induló új, közgazdasági egyetemre. A kollégiumi felvételi részletesebb és érdekesebb volt, mint az egyetemi. Az írásbelin voltak általános emberi magatartásra, egyéni véleményekre vonatkozó és tárgyi tudást vizsgáló kérdések, főleg a magyar irodalomból és történelemből. A szóbeli beszélgetésen mindenkinek a múltjáról, családi hátteréről érdeklődtek és arról, hogy látja a mai világot, mit vár a Nékosztól, mit gondol arról, hogy ő milyen szerepet játszhat majd a kollégiumban. Egyébként Szabó Kálmán, aki évtizedekkel később a Közgáz rektora lett, felvételiztetett a Dózsába, az egyetemre pedig Nagy Tamás, aki kurátorként gyakorlatilag már az egyetem tényleges vezetője volt.

A megnyitó egybeesett a „fordulat éveként” ismertté vált politikai rendszerváltás kezdeteivel. Az évnyitó beszédet Gerő Ernő, a korszak egyik ismert kommunista politikusa és gazdasági vezetője tartotta. Mindannyiunk számára érdekes volt Gerő beszéde s különösen az a rész, amelyben a tervgazdaság lényegét vázolta. Az egyetem és a hallgatók távlatait fejtegetve kijelentette, hogy a mi feladatunk lesz majd a magyar

1 Akadémikus, professor emeritus,Budapesti Corvinus Egyetem, Világgazdaságtan Tanszék 2 DOI: 10.14267/RETP2018.02.15 
tervgazdaság müködtetése és közülünk kerülnek majd ki a magyar népgazdaság vezető szakemberei, „parancsnokai”.

1948-ban, az induláskor az első félévben az új egyetemen még a József Nádor tanárai közül is előadtak. A „bevezetés a kereskedelmtudományokba” tárgy keretében Nyárádi professzor a piacgazdaság alapvető kategóriáival ismertetett meg bennünket. Kuntdner professzor a számvitel nemzetközileg is elismert tudósa az üzleti élet különböző számviteli rendszereiről adott elő. Theisz Ede a statisztika tudományos alapjait tanította. Füley Szántó a magánjogba vezette be hallgatóit. A Nagy Tamás által bevezetett politikai gazdaságtan azonban már az új szellemet képviselte. Rektorrá Rudas Lászlót, a Szovjetunióból hazatért (ott többször is letartóztatott, de életben maradt) marxista filozófust nevezték ki, s ő kezdte el a filozófia tanítását is. Nagy Tamás és Rudas is kitűnő előadók voltak. A második félévben már az új tanárok vették át az oktatást minden más területen is. Egyedül talán Huszár Gézát, a biztosítási matematika világhírü szakemberét vette át az új egyetem.

Az új Közgázon, szemben elődjével, ahol a „mezeizés” volt jellemzö, az órák látogatása kötelező volt $s$ a jelenlétet, éppúgy, mint a hallgatók magatartását, véleménynyilvánítását több szinten és több hálózatban is rendszeresen ellenőrizték. Pártbizottság alakult, s kívülről odahelyezett titkára, aki egyébként gyári munkás volt korábban, függetlenül a hivatalos szervezettől, saját informátori hálózatát is kiépítette. Fő feladatának az „osztályellenségek” felkutatását tartotta. Nemcsak a hallgatók politikai magatartásáról jelentettek neki, hanem a párkapcsolatokról is. Kiderült, hogy külön nyilvántartást vezetett a tanárokról is. Túlzásai miatt szerencsére egy év után eltávolították az egyetemről. Ezt követően, az 1950-es évek első felében az erősen átpolitizált szellem, az állandó ellenőrzés és időnkénti retorziók ellenére, összehasonlítva más magyar egyetemekkel, amelyeket a szélsőségessé váló dogmatizmus, a bizalmatlanség és a félelem légköre uralt, a Közgáz a türelem és a liberalizmus szigete lett.

Az egyetemen a társadalmi munkát igen fontosnak tartották. Mindenkitől elvárták, hogy valamilyen politikai tevékenységben vegyen részt. Én kezdetben a kulturális munkát, majd 1949 végétől a sportot választottam. Az egyetemnek nem volt ugyan tornaterme, de volt csónakháza és számos csónakja. Nagy tömegben álltak rendelkezésre sífelszerelések. A hallgatóknak külön sportüdülöje is volt. Ezek sajnos az évek során fokozatosan leépültek. Az általam választott terület azonban a természet volt, amit nem tudtak leépíteni.

A Haladás Sportegyesület a megalakulása után a BEAC helyébe lépve az egyetemek sportegyesülete lett. Itt néhány kollágával együtt megalakítottuk az egyesület hegymászó szakosztályát, amelynek összegyetemi szinten az elnöke lettem s ugyancsak megválasztottak a Közgáz Haladás hegymászó és síző szakosztálya elnökének. Meggyőztük az illetékeseket, hogy ez az alapjában politikamentesnek deklarált tevékenység stratégiai fontosságú, mert erősíti a szervezetet, kitartásra nevel és megtanítja a térképek használatát is. Az egyetem első osztályú csapata számos tájákozódási versenyt nyert meg és ennek keretében én is első osztályú sportoló lettem.

Keletkezek azonban súlyos problémáim is. 1950-ben kitettek a kollégiumból. Ennek az oka az volt, hogy apámat, akinek 22 hold földje volt, a szeghalmi tanács kuláknak nyilvánította. Ezt követően a tanácstól vagy a pártbizottságtól jött egy levél az egyetem- 
re, amelyben azt javasolták, hogy engem azonnal „távolítsanak el” a népi kollégiumból és az egyetemről. A hallgatói személyzetis, aki erről értesített, azt is kétségesnek tartotta, hogy folytathatom e tanulmányaimat. Nagy Tamás professzor azonban közölte velem, hogy a személyzetis által javasolt „osztályellenség” státusz helyett „egyébnek” minősítenek. Ennek alapján az egyetemen maradhatok, de semmiféle ösztöndíjat nem kaphatok és bizonyos szakokra nem mehetek. Más problémám nem lesz. Gyakorlatilag azonban egy fillér nélkül maradtam. Apámtól ugyanis mindenét elvették, nem tudott támogatni és rövidesen meghalt. Egyik tanárunk, Bognár József professzor, aki akkor belkereskedelmi miniszter volt, kérésemre segített abban, hogy munkához és jövedelemhez jussak. Folytathattam tehát a tanulást, és munkám, ami orosz szakkönyvek fordítása volt, igen hasznosnak bizonyult szakmai tekintetben is.

\section{A NeMZETKöZI gAZDASÁgi ÉS POLITIKAI KÉRDÉSEK: A TÁRgY ÉS A TANSZÉK}

Negyedéves hallgatóként ismerkedtem meg az 1951-52-es tanévben a Nemzetközi gazdasági és politikai ismeretek tárggyal. A tárgy érdekes volt és sok új ismeretet adott. Betekintést vagy inkább kitekintést kaptunk egy olyan világba, amelytől akkor el voltunk zárva. A program két részből állt: egyrészt általános témákból, mint pl. a nemzetközi monopóliumok, a gyarmati rendszer szétesése, a nemzetközi munkásmozgalom, a szociáldemokrácia és a fasizmus, vagy a fegyverkezési verseny (az imperialista országok a fegyverkezési verseny örvényében); másrészt speciális országtémákból, mint az USA, Anglia, illetve az amerikai imperializmus, India, vagy a Brit Birodalom hanyatlása, a kínai forradalom győzelme stb. Külön élmény volt a jegyzet olvasása, amelyik jobbnál jobb sajtóhibákkal volt tele. Kettőre mindmáig emlékszem: az angol munkáspárt „vérbefagyasztási” politikája a bérbefagyasztás helyett, vagy Truman „elvtárs” Truman elnök helyett. A tanszék késõbb hibaigazítót adott ki, amelyik „,hiabigazító” címmel jelent meg.

A tárgyat elöadó Nemzetközi Gazdasági és Politikai Kérdések majd Ismeretek tanszék egy aktatáskaként kezdte „életét” valamikor 1948 őszén. 2018-ban tehát ennek már hetven éve. Az aktatáska barna volt, meglehetõsen nagy és bőrből készült. Az egyetemre helyezett Haász Árpád nevü tanár tulajdona volt. Eredetileg Ausztriában gyártották, tehát jó bőr volt, bár abban az időben még nálunk is lehetett jó minőségű aktatáskákat venni. A táska tulajdonosával együtt települt át Magyarországra. Haász Árpádról majd még külön is szólok. A nagy barna táskát egy akkori hallgató, a tanszék későbbi tanársegédje, a korán elhunyt Kömives Imre hordozta büszkén Haász Árpád után az egyetem folyosóin. Heteken belül a táska kettőre szaporodott. Később a tanszék „kilépett” az aktatáskákból s eleinte egy szobát, majd később többet is kapott. Az ötlet, hogy legyen egy ilyen tanszék az egyetemen egyébként felsőszintű politikai döntés következménye volt, ami azonban nem a tanszékre vonatkozott. Haász Árpádot ugyanis politikai okokból, mint nyugatról hazatért osztrák kommunistát, aki ráadásul a mauthauseni koncentrációs tábort is túlélte, mint politikai fogoly s ilymódon rendkívül gyanús volt, menesztették a Kereskedelmi és Szövetkezeti Miniszteriumból, ahol föosztályvezető volt. Két kevésbé exponált állást ajánlottak fel neki, s ő az egyetemet választotta, ahol egy információs központot is rábíztak egy időre. 
Mire én a tanszékre kerültem, már sok érdekes ember dolgozott ott: a Közgázon 1950-ben végzett Kőmives Imre, aki gyakorlatilag tanszéki titkár volt, Biró Klára, aki az oktatási miniszteriumból került oda, a titokzatos, több nyelvet tudó Porzsolt József, jogász, aki orosz fogságból jött egyenesen a tanszékre. Az 1951-ben végzett Káplár József és Czirják Gyula, a titkárnő, egy nagyon csinos kislány, Fábián Klári, aki akkor már legalább 16 éves volt s frissen került ki a gyorstalpaló gépíró iskolából. Két évfolyamtársam, Plenter János és Kovács Gyula demonstrátorként müködtek a tanszéken. Öket mindannyian irígyeltünk, mert fizetést is kaptak s nyugati újságokat olvashattak. Voltak a tanszéknek külsõ előadói is. Ilyen volt pl. az USA-ból hazatért szerkesztõ, Péter József és a Palesztinából hazajött újságíró, Nemes László, aki igen érdekes élménybeszámolókkal tarkította az órákat s egy tananyagot is írt „Nincs béke az olajfák alatt” címmel. Az előadásokat az akkori szokásoknak megfelelően általában szóról szóra felolvasták. A tanszék minden munkatársa kötelezően részt vett az előadásokon, s így legalábbis látásból ismertük őket. Az előadók a témát rendszerint Marx vagy Lenin idézettel kezdték s Sztálin vagy Rákosi idézettel zárták. Minél fiatalabb volt az előadó, annál több volt az idézet. Haász Árpád néha költőket is idézett, ami akkor az egyetemen szokatlan volt. Goethe idézetére mindmáig emlékszem, ezzel fejezte be ugyanis a nemzetközi munkásmozgalomról szóló előadását:

\author{
Ifju, hív az élet, indulj. \\ Fékezd bölcsen szenvedélyed, \\ Erre int a jó tanács. \\ Szálsz fel a hegy csúcsain túl, \\ Vagy lesüllyedsz mély verembe, \\ Vár szerencse vagy csapás. \\ Lent raboskodsz, fennt uralkodsz, \\ Szenvedsz vagy világot alkotsz, \\ Légy üllő vagy kalapács.
}

E versikét követte a záró mondat: s a világ népei megtanulták, hogyan kell üllőből „kapaláccsá” válni. A kapalács sajtóhiba volt a jegyzetben...

Egy emlékezetes versike megjelent Biró Klári japán jegyzetében is:

Szegény nyomorgó kis faluk,
Nincsen virágjuk sem haluk.

A szerzõ ebben az esetben a japán középkor egyik kiváló költője volt.

Tanáraink közül egyedül az Amerikából hazatért Bebrics Lajos, aki a közlekedés-gazdaságtant tanította, versengett a verselés tekintetében Haász Árpáddal. Igaz, hogy Bebrics amerikai hobo-dalokkal tarkította előadásait, Haász Árpád pedig „csak” verset szavalt.

Szerettem a tárgyat, de semmi szándékom nem volt arra, hogy a tanszékre kerüljek. Engem gyakorlati kérdések érdekeltek. Két állásajánlatom is volt. Bognár József, belkereskedelmi miniszter a Belkereskedelmi Miniszteriumba hívott, a miniszteri titkárságra 
elemzőnek. Déri Tibor, a MÁV egyik vezetője pedig, aki a közlekedési miniszter helyett tartotta az előadásokat, a vasúthoz igyekezett csábítani. Én ez utóbbi területre orientálódtam. A vasúthoz mindenekelött az utazás lehetősége és a témák konkrétsága vonzott. A MÁV-nál töltöttem két nyári üzemi gyakorlatot, s ennek eredményeként, egyik barátommal együtt, 1952 végéig érvényes, első osztályú és minden vonalra szóló MÁV szabadjegy volt tulajdonunkban. Ez lehetővé tette, hogy a hétvégeken Szombathelyre vagy Nyíregyházára, esetleg Békéscsabára vagy Pécsre utazzunk. Ilyenkor vettünk a csarnokban fél kiló olcsó felvágottat, kenyeret és sárgarépát, s belevetettük magunkat a hazai végtelenbe. Egyik nyáron megtanultam a forgalmi tiszti szabályzatot is. A MÁV Nemzetközi Osztályán várt egy érdekesnek ígérkezõ állás.

Tanszéki karrierem úgy kezdõdött, hogy 1952 áprilisában Kőmives Imre, volt kollégiumi társam és jó barátom, aki a tanszék oszlopa és szervezõje volt, áthívott egy italra az egyik közeli csehóba. Titoktartást kérve elmondta, hogy Plenter Jancsit, akit tanársegédként kívántak alkalmazi, nagy megtiszteltetés érte: nemzetközi pályára kerül, $\mathrm{s}$ valószínüleg a Nemzetközi Diákszövetség prágai központjában fog majd dolgozni. A tanszéki állás tehát megüresedett, s mivel én angolul és oroszul tudok, ő rám gondolt. Azt mondta, három feladatom lenne: én lennék Anglia és a Brit Birodalom gazdája, foglalkoznom kellene az ENSZ-el és be kellene dolgoznom Haász elvtárs témáiba s az angol és orosz nyelvü újságokat kellene archiválnom, ami a kivágandó cikkek kijelöléséből és kódolásából áll. Emellett természetesen részt kell majd vennem a vizsgáztatásban is. Ez azonban félévenként csak egyszer fordul elö. A fizetés se rosszabb mint másutt. Nem csaptam azonnal a tenyerébe. Az egyetemen maradás abban az időben nem számított vonzó perspektívának. Két dolog azonban meggondolásra ösztönzött. Egy hónappal később azt a MÁV főosztályvezetőt, aki tanított bennünket és az ottani fõnököm lett volna, letartoztatták. Mindhárman, akik oda készültünk, természetesen ennek ellenére mehettünk volna a MÁV-hoz, de csak egyikünk döntött úgy, hogy vasutas lesz. Én, föként Kőmives Imre nógatására, a tanszék mellett döntöttem. Ezzel kezdetét vette tanszéki „káderezésem” és pályafutásom.

Elöször Porzsolt József beszélgetett velem. Őt föleg orosz és angol nyelvtudásom érdekelte. Oroszul a hadifogságban tanult meg, s mondataiból azonnal rájöttem, hogy sem a nyelvtant sem a szakszavakat nem ismeri kellően. Én akkor már jobban tudtam oroszul. Hetekkel később Haász Árpáddal együtt vizsgáztattak a tárgyból. Haász Árpád közölte, hogy amit elmondtam az jó volt, a tananyagot ismertem, de jobban kellett volna ismernem Lenint. Problémáim voltak Varga Jenő hibáival is. Nem olvastam ugyanis a vonatkozó kötelező irodalmat, Berei Andor bírálatát a kapitalizmus megújulását valló Varga Jenőről. Nem baj, nyugtatta meg Haász Árpádot Porzsolt, majd a tanszéken megismeri Lenint és Varga Jenőt is. Ebben maradtunk. Pár nap múlva behívtak a pártbizottságra, az egyetem személyzeti osztályára s a rektori hivatalba „beszélgetni”. Az egyetem akkori személyzetise egy 35 év körüli teltkarcsú, csinos hölgy volt. Az illetö korábban pincérnőként dolgozott egy körúti presszóban, a beszélgetést követően kezembe adta a tanársegédi kinevezést. A munkát azonban nem vehettem fel. 1952 júliusában behívtak katonának, tartalékos tiszti tanfolyamra. Ez három hónapra szólt, de pecchemre a kiskunhalasi tüzérezrednél felejtettek, ahol élelmezési szolgálatvezetőként dolgoztam. Végül nagy protekcióval (Haász Árpádnak kapcsolata volt az akkori honvédelmi miniszterrel), hat hónap múlva leszereltek s megkezdhettem tanszéki munkámat. 
A tanszéken mindenekelőtt íróasztalt, majd témát és fizetést kaptam. Ezen túl, a Manchester Guardianból kb. hathónapnyi számot, valamint rengeteg Pravdát bíztak rám Plenter Jancsi örökségébõl. A Manchester Guardianok zárt szekrényben voltak. Onnan kellett kikérnem s oda kellett visszatenni a lapokat. Érdekes élmény volt a lap olvasása. Innen értesültem először a koreai háború tényleges történetéről, a kínai-szovjet feszültségről, valamint a szocialista országokban folyó újabb letartóztatásokról. Az íróasztal egy nagyobb helyiségben volt, ahol négyen dolgoztunk. A témám az angol imperializmus hanyatlása és a Brit Birodalom szétesése, valamint az ENSZ lett s kezdő fizetésem havi 1200 forint, amiért akkor a Mátyás Pincében 120 halászlét lehetett venni. A fizetés „halászlé valutában” számítva 1954 után radikálisan csökkent s az 1952-es szintet csak akadémikusként érhettem el ismét jónéhány évvel később, de csak bruttóban.

A munka nem volt érdektelen. Ismerkedésekkel kezdődött; a tanszékvezető fél napot töltött velem előnevelésem érdekében. Először kikérdezett arról, hogy milyen a családi hátterem, megkérdezte, hogy milyen könyveket szoktam olvasni. Hosszasan beszélgettünk Balsac-ról. Ezt követően részletesen elmondta véleményét az angol imperializmusról s közölte velem, hogy milyen feladataim lesznek a brit imperializmus elleni harcban a tanszéken. Megmutatta azt is, hogy miképpen kell a Manchester Guardiant archiválni. Megnyugtatott, hogy nemcsak a Manchester Guardiant kell majd olvasnom. Napokon belül megkapom a Daily Workert, az angol kommunista párt napilapját is. Adott néhány könyvet, $s$ azt ajánlotta, hogy elöször Engels müvét, a „Munkásosztály helyzete Angliában" címüt tanulmányozzam át, s majd számoljak be róla. Igaz, hogy ez német nyelvü volt, s ez a nyelv nem tartozott erős oldalaim közé, de hamarosan találtam egy orosz nyelvü példányt is. Hat hónapot adott arra, hogy megírjam az előadást az angol témában. Miután ő volt a Nemzetközi munkásmozgalom c. téma előadója, megkért, hogy állítsak össsze pár hét alatt egy anyagot az angol Munkáspárt helyzetéröl. Ideadta előadásának szövegét is, amit azonban a jegyzetből már ismertem. Saját magáról nem sokat beszélt, de annál többet érdeklödött arról, hogy mi volt a véleményem a tanszék jegyzetéről.

A tanszék jó kollektívaként működött. A munkaidő akkor még kötött volt, de ezt meglehetősen liberálisan értelmezték. Egymás előadásait kötelező volt meghallgatni. Minden témát megvitattunk. A tanszéken rendszeresek voltak a folyó nemzetközi kérdésekről szervezett viták is. Időnk nem jelentéktelen részét társadalmi munkával és értekezletekkel töltöttük. A társadalmi munka részben az egyetemen belül folyt, részben a IX. kerületben végeztük: előadásokat tartottunk. Egyesek részt vettek a beiskolázásban is. Ez abból állt, hogy középiskolákba látogattak s munkás-paraszt származású hallgatókat agitáltak a továbbtanulásra. Én a szakszervezeti pályára kerültem. Először a szakszervezeti bizalmiaknak kellett a tagsági bélyegeket eljuttatnom, majd én lettem az egyetemi szakszervezeti bizottság kultúrfelelöse. Ez azt jelentette, hogy az összegyetemi dolgozói-oktatói kulturális rendezvényeket kellett szerveznem, évente hármat-négyet. Egyik ilyen rendezvény révén lettem egy „szigorú megrovás” elnevezésű pártfegyelmi tulajdonosa, Porzsolt Jóskával és Bácskai Tamással együtt.

Ami a tanszéki munka technikai részét illeti, ennek nagyrésze előadás, illetve jegyzetírás volt. Anyagainkat kéziratként adtuk át Klárikának, aki csodálatos módon a legolvashatatlanabb fogalmazványokat is le tudta írni. Az olló és a ragasztó alapvető fontosságú munkaeszközök voltak. Egy úriszabót meghazudtoló pontossággal kellett 
megtanulni vágni. A vágás elsősorban a szerkesztés eszköze volt $s$ nem a plagizálásé. $A$ tanszékvezető minden általunk megírt szöveget átnézett s többszörösen átírt. Az átírás egyébként nemcsak fogalmazáskészségünket volt hivatva javítani, hanem óvatosságot is jelentett. Meg kellett tanulni úgy fogalmazni, hogy amit leírtunk, abba még maga Sztálin se köthessen bele. Munkánk egy része egyébként Sztálin idézetek kereséséből állt az éppen aktuális témákhoz. Mentségünkre szolgáljon, hogy ezt még a Számvitel tanszéknek is meg kellett tennie abban az időben.

A tanszék viszonya az egyetem többi tanszékével (összesen 19 tanszék müködött ) nem volt különösen jó. Ez alól csak a szomszédos Pénzügy tanszék képezett kivételt. A legrosszabb kapcsolatban a Politikai Gazdaságtan tanszékkel voltunk, amely tanszék úgy találta, hogy mi túlaktualizáljuk az imperializmust, nem vagyunk elég elméletiek, Ez nem akadályozta meg a PG tanszéket abban, hogy kb. egy éves késéssel átvegye tölünk az érdekesebb anyagokat, sőt témákat is, s magát kiáltsa ki úttürőnek. A másik versenytársunk a Külkereskedelmi tanszék volt, amelyik ugyancsak integrálta témáinkat. Főleg a PG tanszék hangoztatta a hallgatók előtt is, hogy mi átfedjük õket.

A hallgatók többsége szerette a tárgyat, amelyik minden korlátozottsága ellenére nyitottabb volt a világra, mint bármelyik más tárgy az egyetemen.

A tanszék életében az első nagy esemény, mondhatni sorsforduló Sztálin halála volt. A kötelezö tanszéki megemlékezö ülésen Haász Árpád arról beszélt, hogy a második világháború alatt, még a német koncentrációs táborban is Sztálin nevével mentek halálba az emberek. Az SZKP XX. kongresszusa után mondta csak el egy magánbeszélgetés során, hogy a harmincas évek végén Moszkvában volt emigrációban, mint osztrák kommunista. A Komintern feltette neki a kérdést: Moszkvában, a Vörös Professzurán akar-e dolgozni, ahol a külföldi kádereket is képezték, vagy a náci Németországba akar menni illegális pártmunkára. Ö ez utóbbit választotta, mert ott nagyobb biztonságban érezhette magát, hiszen legalább tudta, hogy ki az ellenség. Ha Moszkvában maradt volna, valószinüleg nem maradt volna életben, mert Sztálin az osztrák párt egész vezetését kivégeztette a Molotov-Ribentropp paktumot követően. Mindenesetre a tanszéki ülés mély gyászban zajtott. Én ma csak a tanszékvezető egy érdekes megjegyzésére emlékszem. Egyik munkatárs megkérdezte: és mi lesz most velünk Haász elvtárs? A lakónikus válasz az volt, hogy a nemzetközi munkásmozgalom már ennél nagyobb tragédiákat is túlélt, s most is megújul majd. Haász Árpád egyébként ezekben az években sajátos védekezési mechanizmust fejlesztett ki - az irányitható szenilizmust. Mindig akkor volt szenilis, ha valamilyen kényes témában késztették állásfoglalásra.

Tantantárgyunk megújulása Sztálin halála és a Nagy Imre kormány megalakulása után gyorsabb lett. Az egyetemi tanszékek közül mi hoztuk a legtöbb új témát az egyetemi oktatásba. Ilyen volt pl. az európai szén- és acélközösség, az állam és a nagyvállalatok szerepének megváltozása a gazdaságban, az új államok szerepe a gyarmati felszabadító mozgalmak győzelmét követően, a német kérdés Európában, a kínai forradalom következményei stb. Komolyabban kezdtünk foglalkozni a vezető kapitalista államok és India gazdaságának új vonásaival, a kibontakozóban lévő új tudományos és tecnikai forradalommal. Ebben segített az is, hogy 1954-ben új munkatársat kaptunk a Mexikóból még a negyvenes években hazatért Âdám Görgy személyében, aki a Rajk-per egyik rehabilitáltja volt. 
Nagy Imre egyébként tanárom is volt, de később személyesen is jó viszonyba kerültem vele. 1954-ben én lettem az egyetemi szakszervezeti bizottság elnöke, s Nagy Imre miniszterelnökként is tagja kivánt maradni a pedagógus szakszervezetnek. Én jártam hozzá időnként a tagdíjat beszedni leváltása után is. Néha ő is megkeresett. Találkozásaink során sok kérdésről beszélgettünk. Nagy Imre egy ilyen alkalommal azt ajánlotta, hogy a tanszékünknek foglalkoznia kellene a kapitalizmus agrárszektorával is, mert ott nemcsak agrárválság van, hanem fejlődés is. Haász Árpádnak említettem a javaslatot, aki ettől, s általában a Nagy Imrével való kapcsolattól mereven elzárkózott. Mint 1956-ban kiderült, még moszkvai kapcsolatukból eredően nem szerették egymást. Ádám György javaslata viszont arra vonatkozóan, hogy az új tudományos és technikai forradalommal kellene foglalkoznunk, tetszett mindenkinek. Gyurka tanszéki munkáját hihetetlen energiával és lelkesedéssel kezdte el s már az első tanulmánya is feltünést keltett. A Nemzetközi Gazdasági és Politikai Ismeretek Tanszéke volt ugyanis a szocialista térségben az első intézmény, amelyik meg merte fogalmazni, hogy a nyugati világban egy új, minden eddiginél nagyobb jelentőségü tudományos és technikai átalakulás kezdődött. Ennek deklarálásáért tanszékünk igen éles bírálatot kapott a Politikai Gazdaságtan tanszéktől, azon az alapon, hogy Ádám állítása ellentmond Lenin elméletének a monopóliumokra vonatkozóan. Igaz, hogy ezt nem az egész tanszék, hanem csak egy személy tette szóvá. Ennél szomorúbb volt azonban, hogy a tanszék egyik munkatársa, aki később függetlenített párttitkár lett az egyetemen, 1957-ben a rendőrségi vizsgálatok során Ádám Györgyel kapcsolatban ugyancsak megemlítette e tényt, mint Gyurka nyugatimádatának egyik bizonyítékát. Haász Árpád viszont minden lehetséges módon igyekezett Ádám Györgyöt védeni. 1954-ben került a tanszékre Tzortzisz Dimitrij, aki görög emigránsként került Magyarországra és elvégezte az egyetemet. 16 éves korában már részt vett a németek elleni harcban, majd 1948-ban a görög polgárháborúban Rendkívül müvelt kolléga volt, akit azonban elsősorban a filozófia érdekelt. Dimitrij jelenléte a tanszék állandó vendégévé tette a ciprusi menekült Vasiliu Jorgoszt, a későbbi elnököt is. Tanszékünk keretében dolgozott 1954-től egy afrikai barátunk is, Taher Abdel Basit, későbbi szudáni pénzügyminiszter. Hozzánk került egy iráni menekült kolléga is, aki a Moszadek-kormány idején magasrangú tiszt volt az ottani hadseregben.

A tanszék oktatási programjának megújulása gyors ütemben haladt. Az előadások és a jegyzetek is korszerűbbé váltak. 1956 jelentette a tanszék számára a második nagy változást. A tanszékvezető a Petöfi Kör megalakulásakor arra intett bennünket, hogy ne ússzunk az árral. Tartsuk távol magunkat a politizálástól. Moszkvai tapasztalataira hivatkozott, s azt mondta, hogy az ilyen eseményeket rendszerint nagy tisztogatások és letartóztatások követik. Elvileg mindennel egyetérthetünk, de ne vállaljunk aktív politikai szerepet sehol. Annak ellenére azonban, hogy ellenezte az október 23-ai tüntetést, azon velünk együtt részt vett. A későbbi napokban azonban csak egy-két alkalommal jött be a tanszékre. A beszélgetések során különösen Ádám Gyurkát igyekezett mérsékelni, aki az Értelmiségi Forradalmi Tanács elnöke lett. Én, mint a Szakszervezeti Bizottság elnöke, tagja voltam annak az egyetemi küldöttségnek, amelyik Nagy Imrét kereste fel azzal a céllal, hogy mint egyetemi nemzetőrök, felajánljuk a hallgatók és az oktatók szolgálatait. Kedvesen fogadott bennünket, két bányászdelegációt is várakoztatva. Közölte azonban, hogy hatalma pillanatnyilag csak az íróasztalának a széléig terjed. Az egyetemen is megalakultak a politikai pártok. Egyes oktatók a Szociáldemokrata Pártot, mások a Paraszt- 
pártot s a Kisgazdapártot hozták létre. Néhány hallgató deklarálta a Magyar Hungarista Párt megalakítását. Tanszékünk ezektől a kezdeményezésektől általában távol maradt. A tanszék hivatalsegédjének, Gróf Lajosnénak a kor közhangulatára jellemzö kérdésére mindmáig emlékszem: „mondja Simai elvtárs, a jövőben Haász elvtársat méltóságos úrnak vagy kegyelmes úrnak kell majd szólítanunk?”

A forradalom után a tanszék helyzete is megváltozott. Témái bővültek, lehetőségei javultak. Ezzel együtt számomra is új, váratlan lehetőségek nyíltak...

1961 őszén tértem vissza Genfből, az ENSZ Európai Gazdasági Bizottságából. Az ottani munkám során szerzett ismereteket és tapasztalatokat igyekeztem itthon, a tanszéken is hasznosítani. Megírtam és megvédtem kandidátusi disszertációmat. Ezt követően docens lettem. Rám bízták az egyetemen tanuló külföldi hallgatók ügyeinek menedzselését, s Haász Árpád nyugdíjazása után én lettem a tanszék vezetője. Egyik első teendőm volt a tanszék nevének megváltoztatása Világgazdasági tanszékre s a nevének megfelelően a régi és új kollégákkal együtt megkezdtük a tárgy radikális átalakítását, korszerüsítését. 1964-ben ismét az ENSZ-be mentem dolgozni, a tanszék vezetését pedig Nyilas József vette át. 1968-ban tértem haza New Yorkból. Megírtam és megvédtem akadémiai doktori disszertációmat és kineveztek egyetemi tanárnak. Igyekeztem új témákkal bővíteni a tanszék programját, ami sikerült is. A 70-es évek elején az akadémia Világgazdasági Kutatóintézetének megalakulása után ott lettem fóállású igazgatóhelyetes. Az egyetemet azonban nem hagytam ott, részfoglalkozású egyetemi tanárként tanítottam tovább. A munkámban igyekeztem kamatoztatni a nemzetközi életben szerzett tapasztalatokat, valamint összekapcsolni az akadémiai kutató és az egyetemi oktató munkát.

A Világgazdasági Intézet őstörténetéből és fejlődéséből nem lenne helyes kihagyni a kutatómunka fontosságát sem. Ennek magas színvonalát, eredetiségét jól tükrözik azok a tankönyvek és más kiadványok, amelyek jelentősége messze túlnőtt az egyetem keretein. A tanszék jelentős mértékben járult hozzá a magyar társadalom ismereteinek bővítéséhez és szemléletének formálásához, sajátos nemzeti iskolateremtéséhez, amely döntő tényező volt több egyetemi tanszék létrejöttében és a nemzetközi gazdasági kérdések oktatásának megalapozásában más egyetemeken.

Ennyit röviden az én hetven évemről az egyetemen, valamint a 70 éves Világgazdasági Intézet és egy kicsit az egész egyetem elő- és őstörtéletérõl. 